Jurnal Olahraga \& Kesehatan Indonesia

Volume 1 Nomor 1 (2020)

E-ISSN: 2747-061X

available online at https://jurnal.stokbinaguna.ac.id/index.php/jok

\title{
HUBUNGAN KEMATANGAN PSIKOLOGIS DAN LAMA LATIHAN TERHADAP PRESTASI ATLET OLAHRAGA BELA DIRI
}

\author{
Muslim $^{1}$ *, Nukhrawi Nawir ${ }^{2}$, Djen Jalal ${ }^{3}$ \\ ${ }^{123}$ Universitas Negeri Makassar, Sulawesi Selatan, Indonesia, 90222 \\ *Coressponding Author: muslim@unm.ac.id
}

\section{Keterangan}

Rekam Jejak:

Received, Oktober 2020

Revised, November 2020

Accepted, Desember 2020

Kata Kunci:

Kematangan Psikologis,

Lama Latihan, Atlet,

Olahraga Bela Diri
Penelitian ini bertujuan untuk menemukan jawaban akurat secara ilmiah mengenai Analisis Kematangan Psikologis dan Lama Latihan terhadap Prestasi Atlet Olahraga Bela Diri Program Sulawesi Selatan Maju II. Penelitian ini menggunakan penelitian Ex Post Facto yang bertujuan untuk mengkaji secara sistematis dan empiris dimana peneliti tidak mengontrol variabel independen secara langsung karena keberadaan variabel tersebut telah akurat. Kesimpulan hubungan antara variabel-variabel tersebut didasarkan pada perbedaan yang menyertai variabel independen dan variabel dependen. Teknik pengambilan sampel yang digunakan adalah purposive sampling dengan jumlah sampel 43 atlet bela diri Sulawesi Selatan Maju II. Hasil penelitian menunjukkan bahwa: (1) Berdasarkan analisis uji chi-square terhadap 43 Atlet Bela Diri Program Sulawesi Selatan Maju II didapatkan nilai $\mathrm{p}=0,01(<0,05)$, artinya terdapat hubungan yang signifikan antara Kematangan Psikologis dan prestasi yang diperoleh atlet bela diri Program Sulawesi Selatan Maju II., (2) dari 43 Atlet Bela Diri Program Sulawesi Selatan Maju II diperoleh $\mathrm{p}$ value $=0,01(<0,05)$, artinya ada hubungan yang signifikan antara Lama Latihan dan prestasi yang diperoleh Atlet Bela diri Program Sulawesi Selatan Maju II., (3) Berdasarkan hasil penghitungan, ditemukan bahwa terdapat hubungan yang signifikan antara variabel Kematangan Psikologis dan Lama Latihan terhadap prestasi atlet bela diri terhadap Sulawesi Selatan Maju II. 


\section{PENDAHULUAN}

Provinsi Sulawesi Selatan merupakan lumbung Atlet Nasional Indonesia terutama cabang olahraga bela diri. Hal ini tidak dapat kita pungkiri bahwa setiap pelaksanaan Sea Games ada puluhan atlet yang berasal dari Provinsi Sulawesi Selatan yang mengikuti program pelatnas. Berdasarkan fakta dari PON ke PON Provinsi Sulawesi Selatan mengalami peningkatan perolehan medali dalam setiap event Nasional tersebut terutama cabang olahraga bela diri yang merupakan olahraga andalan Provinsi Sulawesi Selatan. Namun keberhasilan tersebut tidak dibarengi dengan ketersediaan data yang akurat apakah prestasi tersebut didukung oleh tingkat Kematangan Psikologis dan lama latihan pada Atlet cabang olahraga bela diri. Program pembinaan Atlet jangka panjang yang sistematis, terencana, terpadu dan berkesinambungan yang di lakukan oleh KONI Provinsi Sulawesi Selatan adalah kelanjutan dari Sulawesi Selatan Bangkit tahun 2005-2008 kemudian di susul Program Sulawesi Selatan Maju I 2009-2012 kemudian yang berlangsung saat ini yaitu program Sulawesi Selatan Maju II dan di resmikan pada tanggal 20 Oktober 2013. Dengan adanya Program Sulawesi Selatan Maju II ini di harapkan Atlet-Atlet Provinsi Sulawesi Selatan dapat meraih prestasi dalam olahraga yang ditekuninya pada PON XIX-2016 Jawa Barat.

Di dalam Undang-Undang Republik Indonesia Nomor 3 tahun 2005 tentang Sistem Keolahragaan Nasional secara eksplisit menegaskan bahwa Olahraga prestasi adalah olahraga yang membina dan mengembangkan olahragawan secara terencana, bejenjang, dan berkelanjutan melalui kompetisi untuk mencapai prestasi dengan dukungan ilmu pengetahuan dan teknologi keolahragaan. Dari uraian undang-undang tersebut dapat di simpulkan bahwa pembinaan olahraga prestasi membutuhkan jangka waktu yang berjenjang (lama latihan) dan juga didukung oleh berbagai disiplin ilmu. Haag dalam Jurnal Iptek Olahraga (2011: 245) mengatakan ilmu keolahragaan itu tersusun dari tujuh bidang teori dasar, yaitu Kesehatan Olahraga, Biomekanika Olahraga, Psikologi Olahraga, Pedagogi Olahraga, Sosiologi Olahraga, Sejarah Olahraga, dan filsafat Olahraga. Jadi Psikologi olahraga merupakan salah satu dari ketujuh bidang teori yang merupakan batang tubuh Ilmu Keolahragaan. Jadi, untuk memperoleh prestasi atau performa olahraganya, seorang Atlet terkhusus atlet bela diri harus memiliki Kematangan Psikologis, sehingga Atlet tersebut dapat mengontrol Emosi, stres, kecemasan, Frustasi, arousal dan agresifitas sehingga ia dapat berlatih dan bertanding dengan semangat, tekad, dedikasi dan tanpa masalah non teknis lainnya baik secara internal maupun eksternal. Menurut Husdarta (2011: 70) emosi yang tidak terkendali (uncontrol) dapat mengganggu keseimbangan psiko-fisiologi (seperti gemetar, lemas, keluar keringat dingin, kejang otot, dll) dan membuyarkan konsentrasi. Pada gilirannya berimbas pada penampilan dan prestasi.

Oleh sebab itu, di dalam Renstra KONI (2012: 1), disebutkan bahwa pengembangan dan kemajuan cabang olahraga yang menjadi koordinasi KONI Provinsi Sulawesi Selatan dilakukan secara terus menerus dan berkesinambungan. KONI Provinsi Sulawesi Selatan menggunakan pola pikir bahwa seorang Atlet yang berprestasi harus di ciptakan dengan menggunakan pendekatan IPTEK Olahraga secara benar dan baik, dan Atlet tidak datang sendiri atau turun dari langit dan langsung berprestasi. Atlet berprestasi butuh proses dan waktu yang sangat penjang, seperti apa yang di kemukakan oleh Yesis dan Turbo dalam Santosa \& Sidik (2012: 322) bahwa penguasaan keterampilan suatu kecabangan olahraga untuk dapat sampai kepuncaknya memerlukan waktu yang sangat panjang. Makin banyak pembelajaran gerak yang harus dilakukan, makin banyak waktu yang diperlukan untuk sampai pada penguasaan keterampilan tingkat puncak.

Keterampilan puncak yang dimaksud tersebut merupakan pencapaian prestasi dalam event olahraga yang mana pengertian prestasi olahraga menurut Santosa \& Sidik (2012: 151) prestasi olahraga adalah kemampuan fisiologis yang maksimal dari seorang Atlet pada suatu waktu dalam sesuatu cabang olahraga tertentu. Untuk mencapai prestasi puncak, selain Kematangan Psikologis latihan secara rutin merupakan faktor pendukung utama dalam 
pencapaian prestasi. Ini sesuai dengan apa yang di kemukakan oleh Nawir (2008: 7) latihan adalah suatu aktifitas fisik yang dilakukan secara sistematis, teratur, kontinu, terorganisasi dengan dosis latihan ditingkatkan secara progressif dan overload yang bertujuan meningkatkan kemampuan fungsional dan psikologi tubuh, sehingga mempermudah mempelajari gerakangerakan teknik olahraga dan akhirnya dapat mencapai prestasi optimal dalam suatu cabang olahraga. Sehubungan dengan ini maka KONI Provinsi Sulawesi Selatan dalam melaksanakan tugas dan fungsinya senantiasa berorientasi kepada program yang dapat langsung dirasakan dan bermanfaat bagi Atlet cabang olahraga anggota KONI Provinsi Sulawesi Selatan. Berdasarkan penjelasan tersebut di atas, dapat di simpulkan bahwa pencapaian prestasi olahraga tidak hanya di dapatkan begitu saja, melainkan memerlukan waktu dan proses pembinaan jangka panjang, proses pembinaannya melalui suatu proses latihan yang terprogram, tersusun, sistematis, kontinu dilakukan secara berulang-ulang, dan makin hari makin bertambah beban latihannya sesuai dengan prinsip latihan.

Oleh karena itu, jika melihat keberhasilan prestasi yang di peroleh atlet bela diri Sulawesi Selatan dalam mendulang medali pada PON XVIII di Riau, maka peneliti bermaksud menganalisis apakah Kematangan Psikologis dan lama latihan merupakan kunci dari kesuksesan meraih prestasi. Karena Kematangan Psikologis merupakan salah satu faktor penentu dari keberhasilan seorang Atlet dalam meraih prestasi dalam perlombaan dan pertandingan. Selain itu, Lama latihan juga dianggap sebagai faktor penentu keberhasilan Atlet meraih prestasi. Oleh sebab itu, peneliti bermaksud mengadakan analisis apakah kedua faktor tersebut di atas memiliki dampak yang signifikan dalam pencapaian puncak prestasi seorang atlet bela diri.

\section{METODE}

Metode penelitian dalam penelitan ini adalah penelitian Ex Post Facto. Menurut Kerlinger dalam Emzir (2013: 119) penelitian Ex Post Facto adalah penyelidikan empiris yang sistematis di mana peneliti tidak mengendalikan variabel bebas secara langsung karena eksistensi dari variabel tersebut telah terjadi, atau karena variabel tersebut pada dasarnya tidak dapat di manipulasi. Kesimpulan tentang adanya hubungan antara variabel tersebut dibuat berdasarkan perbedaan yang mengiringi variabel bebas dan variabel terikat, tanpa intervensi langsung.

Variabel adalah objek penelitian, atau apa yang menjadi fokus di dalam suatu penelitian. Langkah awal yang digunakan untuk mengungkapkan sejauh mana adanya hubungan yang signifikan antara variabel bebas (independent variable) yang terdiri dari 2 (dua) variabel yaitu; Kematangan Psikologis dan Lama Latihan dengan variabel terikat (dependent variable) yaitu; Prestasi Atlet Sulawesi Selatan Maju II Pada PON VIII Riau. Untuk mendapatkan hasil penelitian ini, maka penelitian menggunakan tehnik analisis korelasional, melihat seberapa besar pengaruh independent variable terhadap dependent variable.

Penelitian ini dilakukan untuk mengungkap hubungan Kematangan Psikologis dan Lama Latihan terhadap Prestasi Atlet Cabang Olahraga Bela diri Program Sulawesi Selatan Maju II. Untuk mengetahui nilai Kematangan Psikologis dan nilai lama latihan maka dilakukan pengamatan melalui data-data primer setiap Atlet Cabang Olahraga Bela diri yang masuk dalam Program Sulawesi Selatan Maju II yang dimiliki oleh KONI Provinsi Sulawesi Selatan.

\section{HASIL \& PEMBAHASAN}

Hubungan Kematangan Psikologis terhadap Prestasi Atlet Cabang Olahraga Bela Diri

Dari hasil penelitian yang telah dilakukan dengan menggunakan analisis uji chi-square bahwa Atlet cabang olahraga bela diri yang masuk dalam program Sulawesi Selatan maju 2 adalah atlet yang memiliki nilai Kematangan Psikologis yang masuk dalam kategari Baik Sekali dan Baik. Hasil analisis uji chi-square ditemukan bahwa ada hubungan yang signifikan Kematangan Psikologis terhadap Prestasi Atlet Cabang Olahraga Bela diri Program Sulawesi Selatan Maju II dalam meraih prestasi. Hasil Pengujian hipotesis pertama menunjukkan ada 
hubungan yang signifikan antara Kematangan Psikologis terhadap Prestasi Atlet Cabang Olahraga Bela diri Program Sulawesi Selatan Maju II. Terlihat pada tabel 6 menunjukkan bahwa dari 43 Atlet Cabang Oalahraga Bela diri Program Sulawesi Selatan Maju II, didapatkan 15 (45,5\%) memiliki Kematangan Psikologis baik sekali dengan prestasi prioritas 1, 5 (15,2\%) memiliki Kematangan Psikologis baik sekali dengan prestasi prioritas 2, $11(33,3 \%)$ memiliki Kematangan Psikologis baik sekali dengan prestasi prioritas 3, 2 (6,1\%) memiliki Kematangan Psikologis baik sekali dengan prestasi prioritas 4 . Kemudian, didapatkan $3(30 \%)$ memiliki Kematangan Psikologis baik dengan prestasi prioritas 1, 2 (20\%) memiliki Kematangan Psikologis baik dengan prestasi prioritas 2, 3 (30\%) memiliki Kematangan Psikologis baik dengan prestasi prioritas 3, $2(20 \%)$ memiliki Kematangan Psikologis baik dengan prestasi prioritas 4. Dengan nilai $\mathrm{p}=0,010$ ( lebih kecil dari 0,05) ini berarti ada hubungan yang signifikan antara Kematangan Psikologis dan prestasi yang diperoleh oleh Atlet Cabang Olahraga Bela diri Program Sulawesi Selatan Maju II.

Dengan demikian untuk melengkapi keahlian-keahlian yang dimiliki seorang Atlet cabang olahraga bela diri diperlukan juga Kematangan Psikologis yang dapat menunjang Perolehan prestasi atlet cabang olahraga bela diri program Sulawesi Selatan maju II. Sebab dalam cabang olahraga bela diri, dengan banyaknya aksi yang harus dilakukan baik itu secara terprogram dan kontiniu, atau sesuatu yang sudah terprediksi maupun sesuatu yang tidak terprediksi akan terjadi dilapangan sehingga seorang Atlet Cabang Olahraga Bela diri dituntut untuk membekali dirinya dengan Kematangan Psikologis yang baik, dan selanjutnya mampu untuk menerjemahkan dan mengaplikasikan Kematangan Psikologis tersebut dalam suatu event atau pertandingan yang di hadapi.

Atlet sebagai manusia biasa, tidak akan pernah luput dari berbagai permasalahanpermasalahan yang akan datang menghampiri dirinya sehingga dapat menghambat pencapaian penyesuaian dirinya terhadap suatu latihan. Permasalah-permasalahan itu dapat timbul baik secara internal dan external, namun ini tidak akan dapat menjadi penghalang jika dalam diri Atlet tersebut sudah tertanam prinsip keseimbangan diri (homeostatic eqiulibrium), bahwa pada tubuh manusia selalu ada upaya untuk mencari keseimbangan dengan sendirinya.Oleh sebab itu, guna mencari keseimbangan tersebut dibutuhkan berbagai tahapan tahapan latihan baik itu secara otodidat maupun lewat bantuan orang lain. Keadaan psikologis seorang atlet sangat di tentukan oleh pengalaman pengalaman bertanding atau perlombaan yang diikuti. Secara fisiologis perkembangan psikologis seorang atlet yang di peroleh dari pengalaman bertanding di tunjukkan dengan bertambahnya jumlah cabang denrit neuron pada bagian otak dengan bertambahnya jumlah denrit neuron pada bagian otak melalui latihan latihan psikologi maka Kematangan Psikologis seorang atlet akan semakin baik.

Adapun prioritas yang menunjukkan tingkatan-tingkatan Atlet yang masuk dalam program Sulawesi Selatan Maju II merupakan hasil prestasi yang diperoleh pada saat PON ke XVIII di Pekanbaru Riau. Dengan demikian diharapkan setiap Atlet Cabang Olahraga Bela diri yang masuk dalam Program Sulawesi Selatan Maju II perlu memiliki Kematangan Psikologis yang baik apabila ingin mencapai suatu prestasi dalam suatu event atau pertandingan. Karena jika seorang Atlet telah memiliki Kematangan Psikologis maka Atlet tersebut telah memiliki pribadi yang tingkah lakunya telah terorganisasi secara sentral dengan intensi-intensi yang sadar berupa harapan-harapan aspirasi-aspirasi dan impian-impian, yang mengatur energi positif dalam diri Atlet tersebut dalam situasi olahraga sehingga dapat mengatasi faktor extrenal dan internal yang dapat mempengaruhi penampilan (performance) dalam meraih suatu prestasi dalam suatu event atau pertandingan.

Hubungan Lama Latihan terhadap Prestasi Atlet Cabang Olahraga Bela Diri

Berdasarkan hasil pengolahan data dengan menggunakan program SPSS 21 Hasil analisis uji chi-square ditemukan bahwa ada hubungan yang signifikan Lama Latihan terhadap Prestasi Atlet Cabang Olahraga Bela diri Program Sulawesi Selatan Maju II. Hasil penelitian yang telah di lakukan, dapat kita lihat pada tabel 8 menunjukkan bahwa dari 43 Atlet Cabang Oalahraga 
Bela diri Program Sulawesi Selatan Maju II, didapatkan 15 (42,9\%)Atlet memiliki lama latihan masuk dalam kategori lama dengan prestasi prioritas 1, 5 (14,3\%) Atlet memiliki lama latihan masuk dalam kategori lama dengan prestasi prioritas 2, 13 (37,1\%) Atlet memiliki lama latihan masuk dalam kategori lama dengan prestasi prioritas 3, dan $2(5,7 \%)$ Atlet memiliki lama latihan masuk dalam kategori lama dengan prestasi prioritas 4. Kemudian, didapatkan $3(37,5 \%)$ Atlet memiliki lama latihan masuk dalam kategori Baru dengan prestasi prioritas 1, $2(25 \%)$ Atlet memiliki lama latihan masuk dalam kategori baru dengan prestasi prioritas 2, 1 (12,5\%) Atlet memiliki lama latihan masuk dalam kategori baru dengan prestasi prioritas 3, dan $2(25 \%)$ Atlet memiliki lama latihan masuk dalam kategori baru dengan prestasi prioritas 4 dengan nilai $\mathrm{p}=0,010$ (lebih kecil dari 0,05) ini berarti ada hubungan yang signifikan antara Kematangan Psikologis dan prestasi yang diperoleh oleh Atlet Cabang Olahraga Bela diri Program Sulawesi Selatan Maju II.

Dengan Demikian dapat disimpulkan bahwa pencapaian suatu prestasi tidak serta merta didapatkan begitu saja, melainkan butuh proses yang cukup panjang, yang mana proses latihan tersebut dilakukan secara kontinu, berkesinambungan terprogram dan terarah sesuai program latihan yang telah di susun oleh seorang pelatih terhadap Atletnya. Segala jenis aktivitas fisik yang kita lakukan sehari-hari secara sadar, sistematis, bertahap, berulang-ulang teratur dan terencana, dengan waktu yang relatif lama untuk meningkatkan kondisi dan potensi fisik seseorang Atlet, akan membentuk kondisi atlet menjadi terampil, kuat dan memiliki kecakapan yang baik dalam menguasai teknik gerak sehingga terbentuklah suatu keterampilan khusus yang dapat di tampilkan dalam suat event atau pertandingan untuk meraih prestasi atau juara. Jadi pencapaian suat prestasi tidak dapat kita peroleh hanya dengan berlatih satu hari saja melainkan ada proses latihan jangka panjang yang harus dilakukan oleh seorang atlet untuk meraih prestasi maksimal atau juara dalam suat event atau pertandingan.

Hubungan Kematangan Psikologis dan Lama Latihan terhadap Prestasi Atlet Cabang Olahraga Bela Diri

Hasil analisis uji chi-square ditemukan bahwa ada hubungan yang signifikan Kematangan Psikologis dan Lama Latihan terhadap Prestasi Atlet Cabang Olahraga Bela diri Program Sulawesi Selatan Maju II, terlihat pada tabel 9 menunjukkan bahwa dari 43 Atlet Cabang Oalahraga Bela diri Program Sulawesi Selatan Maju II, didapatkan 18 (41,9\%) Atlet memiliki lama latihan dengan prestasi prioritas 1, $7(16,3 \%)$ Atlet memiliki lama latihan dengan prestasi prioritas 2, $14(32,6 \%)$ Atlet memiliki lama latihan dengan prestasi prioritas 3, dan $4(9,3 \%)$ Atlet memiliki lama latihan dengan prestasi prioritas 4. Kemudian, didapatkan 18 (41,9\%) Atlet memiliki Kematangan Psikologis dengan prestasi prioritas 1, 7 (16,3\%) Atlet memiliki Kematangan Psikologis dengan prestasi prioritas 2, 14 (32,6\%) Atlet memiliki Kematangan Psikologis dengan prestasi prioritas 3, 4 (9,3\%) Atlet memiliki Kematangan Psikologis dengan prestasi prioritas 4 dengan nilai $\mathrm{p}=0,010$ (lebih kecil dari 0,05 ) ini berarti ada hubungan yang signifikan antara Kematangan Psikologis dan lama latihan terhadap prestasi yang diperoleh Atlet Cabang Olahraga Bela diri Program Sulawesi Selatan Maju II.

Dari hasil analisis data tersebut, data yang di peroleh dari nilai Kematangan Psikologis dan Lama Latihan Atlet Cabang Olahraga Bela diri yang masuk dalam program Sulawesi Selatan maju II menunjukkan bahwa atlet yang masuk dalam prioritas 1 di dominasi oleh atlet yang memiliki nilai Kematangan Psikologis tinggi atau masuk dalam kategori baik sekali dan memiliki lama latihan cukup lama. Keadaan psikologis seorang Atlet sangat di tentukan oleh pengalaman pengalaman bertanding atau perlombaan yang diikuti. Secara fisiologis perkembangan psikologis seorang Atlet yang di peroleh dari pengalaman bertanding di tunjukkan dengan bertambahnya jumlah cabang denrit neuron pada bagian otak.

Aktifitas fisik yang dilakukan sehari-hari melalui latihan yang terprogram dan dilakukan secara kontinu kemudian di barengi dengan pengalaman-pengalaman bertanding dapat menumbuhkan denrit-denrit tentang pengalaman dan latihan yang di lakukan. Kondisi fisik atau kegiatan fisik sangat berpengaruh terhadap keadaan psikologis seseorang. Keadaan psikologis 
merupakan bagian dari respon otak terhadap suatu rangsangan baik itu secar internal maupun eksternal. Di dalam latihan dapat membantu pelepasan faktor neurotropik yang dapat membantu memelihara jaringan saraf.

Oleh karena itu untuk menciptakan Atlet yang berprestasi diperlukan latihan yang dilakukan dalam waktu yang lama (sekitar 8-10 tahun keatas) dalam satu cabang olahraga secara konsisten, kontiniu bertahap dan terprogram sehingga latihan tersebut akan membuat seorang atlet akan menjadi mahir baik itu secara fisik, tehnik, taktik dan strategi terhadap cabang olahraga yang di tekuni. Disamping itu diperlukan juga Kematangan Psikologis yang baik dalam diri Atlet agar dapat memaksimalkan performa fisik, tehnik, taktik dan strategi pada saat melakukan pertandingan. Jadi dapat disimpulkan bahwa Kematangan Psikologis dan Lama Latihan merupakan satu kesatuan yang tidak bisa dipisahkan dalam menciptakan Atlet yang berprestasi.

\section{SIMPULAN}

Berdasarkan penjabaran hasil dan pembahasan, maka penelitian ini dapat disimpulkan sebagai berikut: (1) Ada hubungan yang signifikan antara Kematangan Psikologis terhadap Prestasi Atlet Cabang Olahraga Beladairi Program Sulawesi Selatan Maju II dengan hasil analisis nilai $p=0,010$ ( lebih kecil dari 0,05) ini berarti ada hubungan yang signifikan antara Kematangan Psikologis dan prestasi yang diperoleh oleh Atlet Cabang Olahraga Bela diri Program Sulawesi Selatan Maju II. (2) Ada hubungan yang signifikan antara Lama Latihan terhadap Prestasi Atlet Cabang Olahraga Beladairi Program Sulawesi Selatan Maju II dengan hasil analisis nilai $\mathrm{p}=0,010$ (lebih kecil dari 0,05) ini berarti ada hubungan yang signifikan antara Kematangan Psikologis dan prestasi yang diperoleh oleh Atlet Cabang Olahraga Bela diri Program Sulawesi Selatan Maju II. (3) Ada hubungan yang signifikan antara Kematangan Psikologis dan Lama Latihan terhadap Prestasi Atlet Cabang Olahraga Beladairi Program Sulawesi Selatan Maju II.

\section{DAFTAR PUSTAKA}

Baihaqi, MIF. (2011). Psikologi Pertumbuhan, Kepribadian Sehat untuk Mengembangkan Optimisme. Bandung: Remaja Rosdakarya.

Beding, Bona. 2000. Membangun Karakter Bangsa Melalui Olahraga. Jakarta: Grasindo.

Biro Humas dan Hukum. (2010). Undang-Undang Republik Indonesia Nomor 3 Tahun 2005 Tentang Sistem Keolahragaan Nasional. Jakarta: Kementerian Pemuda \& Olahraga Republik Indonesia.

Calvin, \& Lindzey. (1993). Psikologi Kepribadian 3; Teori-Teori Sifat dan Behavioristik. Yogyakarta: Kanisius.

Departemen Pendidikan Nasional. (2000). Pedoman dan Modul Pelatihan Kesehatan Olahragawan Pelajar. Jakarta: Pusat Pengembangan Kualitas Jasmani.

Dimyati, Herwin,. \& Triani, hastuti. (2011). Pemetaan dan Karakteristik Psikologis Atlet SKO dan PPLP, Jurnal IPTEK Olahraga Volume 13, Nomor 3. Jakarta: Kementrian Pemuda dan Olahraga RI.

Effendi, EU. (2012). Pengantar Psikologi. Bandung: Angkasa.

Eko, HW. (2007). Kamus Bahasa Indonesia. Jakarta: Palanta.

Emzir. (2013). Metodologi Penelitian Pendidikan: Kuantitatif dan Kualitatif. Jakarta: Rajawali Pers.

Eric, Jensen. (2008). Memperkaya Otak: Cara Memaksimalkan Potensi Setiap Pembelajar. Jakarta: PT. Indeks. 
Grosser, Strischka, \& Zimmermann. (2001). Latihan Fisik Olahraga, (Diterjemahkan Oleh Paulus Levinus Pasurney); Pusat Pendidikan Penataran Bidang Penelitian \& Pengembangan. Jakarta: KONI Pusat.

Gunarsa, SD. (2008). Psikologi Olahraga Prestasi. Jakarta: Gunung Mulia.

Griwijoyo, Santosa., \& Sidik, Dikdik Zafar. (2012). Ilmu Faal Olahraga (Fisiologi Olahraga). Bandung: Remaja Rosdakarya.

Herman. (2011). Psikologo Olahraga. Makassar: Jurusan Pendidikan Kepelatihan Olahraga FIK Universitas Negeri Makassar.

Husdarta, H.J.S. (2011). Sejarah dan Filsafat Olahraga. Bandung: Alfabeta.

Husdarta, H.J.S. (2011). Psikologi Olahraga. Bandung: Alfabeta.

Husdarta, H.J.S., \& Kusmaedi, Nurlan. (2010). Pertumbuhan dan Perkembangan Peserta Didik (Olahraga dan Kesehatan). Bandung: Alfabeta.

James, WK. (2014). Biopsikologi, Biological Psychology. Jakarta: Salemba Humanika.

Khairani, Makmum. (2013). Psikologi Umum. Yogyakarta: Aswaja Pressindo.

KONI Pusat, Bidang Penelitian \& Pengembangan. (2014). Analisis Kekuatan, Tantangan, Peluang dan Strategi Indonesia Menyongsong Multi Ajang Asian Games XVII 2014, SEA Games XXVIII 2015, Olympic Games XXXI 2016. Jakarta: Gramedia.

Lubis, Johansyah. (2013). Panduan Praktis Penyusunan Program Latihan. Jakarta: Rajawali Pers.

Marwan Lis., Cucu Hidayat, \& Eka Wahyu Hidayat. (2011). Upaya Peningkatan Prestasi Senam Artistik Melalui Proses Menggunakan Media Rekam, Jurnal IPTEK Olahraga Volume 13, Nomor 2. Jakarta: Kementrian Pemuda dan Olahraga RI.

Nawir, Nukhrawi. (2008). Disertasi, Perubahan Predominan Filamen Aktin Dan Miosin Otot Skelet pada Dosis Latihan Fisik Interval Anaerobik 1:1, 1:2, \& 1:3. Surabaya: Universitas Airlangga.

Nurhidayah \& Selviania. (2012). Prestasi Olahraga paralimpian Indonesia, Kajian prespektif Psikologi, Jurnal IPTEK Olahraga, Volume 14, Nomor 3. Jakarta: Kementrian Pemuda dan Olahraga RI.

Program Pasca Sarjana, Universitas Negeri Makassar. (2010). Pedoman Penulisan Tesis dan Disertasi. Makassar: Badan Penerbit UNM.

Pengurus KONI Provinsi Sulawesi Selatan. (2012). Rencana Program Kerja KONI Provinsi Sulawesi Selatan Tahun 2012. Makassar: KONI Sulawesi Selatan.

Riduwan. (2008). Metode \& Teknik Menyusun Tesis. Bandung: Alfabeta.

Sarwono, SW. (2007). Psikologi Remaja. Jakarta: Raja Grafindo Persada.

Scheuneman, Timo. (2012). Kurikulum Sepak Bola Indonesia Untuk Usia Dini (U5-U12), Usia Muda (U13-U20) \& Senior. Jakarta: PSSI.

Siregar, Sofyan. (2013). Statistika Parametrik untuk Penelitian Kuantitatif; dilengkapi dengan perhitungan manual dan aplikasi SPSS versi 17. Jakarta: Bumi Aksara.

Widodo, Bernardus. (2013). Perilaku Disiplin Siswa Ditinjau Dari Aspek Pengendalian Diri (Self Control) dan Keterbukaan Diri (Self Disclosure) Pada Siswa SMK Monosari Caruban Kabupaten Madiun, Widya Warta No. 01 tahun XXXV II. Madiun: Widya warta.

Wirawan, SS. (2012). Pengantar Psikologi Umum. Jakarta: Rajawali Pers.

Yulianto, Fitri, \& Nashori. (2006). Kepercayaan Diri dan Prestasi Atlet Taekwondo Daerah Istimewa Yogyakarta. Jurnal Psikologi Universitas Negeri Diponegoro; Vol. 3, No. 1. Yogyakarta: Universitas Negeri Diponegoro. 